Al-Bidayah : jurnal pendidikan dasar Islam

Volume 13, Number 1, June 2021

ISSN: 2549-3388 (online)

Available online at https://jurnal.albidayah.id

Submitted: September 7, 2019, Accepted: June 26, 2021

\title{
DEVELOPING THEMATIC LEARNING MODULE BASED ON \\ ETHNOSCIENCE ORIENTED OUTDOOR LEARNING STRATEGY TO IMPROVE STUDENT'S LEARNING OUTCOMES IN PRIMARY SCHOOL
}

\author{
Andika Adinanda Siswoyo ${ }^{1}$ \\ Universitas Trunojoyo Madura, Indonesia ${ }^{1}$ \\ E-mail: andika.siswoyo@trunojoyo.ac.id ${ }^{1}$
}

DOI: 10.14421/al-bidayah.v13i1.283

\begin{abstract}
The difficulty of students to understand science concepts in thematic learning requires innovation of the appropriate teaching materials. Meanwhile, the existence of salt ponds around students can be used as oriented outdoor learning. Therefore, this study aims to develop ethnoscience-based thematic modules implemented through outdoor learning strategies. The subjects were 40 grade VI students at Public Elementary School (or called SDN) Padelegan Pamekasan with different academic abilities and gender. The test results of learning data validity and effectiveness of modules were obtained through observation sheet instruments and questionnaires. According to the results, (1) validity modules were in the valid category, based on assessment of material and learning design experts, (2) the module's effectiveness is in the effective category. Therefore, it can be concluded that the module strategy is worth using and improving science understanding for thematic learning in elementary schools.
\end{abstract}

Keywords: modul ethnoscience; outdoor learning; primary school

\section{INTRODUCTION}

The government has made efforts to preserve culture by incorporating elements of local culture into learning at every educational level, including elementary schools. Local wisdom is very important as an element in reducing environmental degradation. ${ }^{1}$ Therefore, there need to be subjects that contain elements of local culture. ${ }^{2}$ As a solution to this, it is necessary to learn ethnoscience that connects the local culture to its learning experience.

Several countries that use the ethnoscience approach show the correlation between curriculum and culture impacts American-Indian students in understanding what they are learning in the context of culture, science, and mathematics. ${ }^{3}$ The collaboration of local

${ }^{1}$ I Wayan Kasa, "Local Wisdom In Relation To Climate Change," Journal of ISSAAS 17, no. 1 (2011): 22-27, https://www.cabdirect.org/cabdirect/abstract/20113247888.

${ }^{2}$ Usmeldi and Risda Amini, "The Effect Of Integrated Science Learning Based On Local Wisdom To Increase The Students Competency," Journal of Physics: Conference Series 1470 (February 2020): 012028, https://doi.org/10.1088/1742-6596/1470/1/012028.

${ }^{3}$ David M. Davison and Kenneth W. Miller, "An Ethnoscience Approach to Curriculum Issues for American Indian Students," School Science and Mathematics 98, no. 5 (1998): 260-65, https://doi.org/10.1111/j.1949-8594.1998.tb17299.x. 
wisdom (IN) and traditional ecological knowledge (TEK) can increase motivation and self-esteem for indigenous students. ${ }^{4}$

Learning using ethnoscience is believed to change the approach from teacher to student-centered learning. ${ }^{5}$ Furthermore, ethnoscience is an effort to create a learning atmosphere and experiences by collaborating with culture as part of the learning process. ${ }^{6}$ A good education needs to facilitate students in science. However, the availability of appropriate learning materials at the primary school level is not appropriate and has not integrated the local culture. Meanwhile, the difference between the ethnoscience module used and the previous study is that an outdoor model is integrated when learning using the module.

Learning materials are also important because they serve as tools in educational activities. $^{7}$ One of them is a module, which is relevant to use in thematic learning. Modules have self-instructional characteristics, meaning they can help and encourage readers to teach themselves. ${ }^{8}$ Furthermore, learning with the module is expected to help students learn independently with or without the guidance of their teacher. In addition, students can accommodate their prior knowledge through modules.

Madura Island is one of the salt-producing areas, with various tribes and diverse cultures. This island is the largest salt producer in east Java and Nationally; hence it is synonymous with the salt island. ${ }^{9}$ The culture and habits of the people around the salt

${ }^{4}$ Elizabeth McKinley, "Locating The Global: Culture, Language And Science Education For Indigenous Students," International Journal of Science Education 27, no. 2 (January 1, 2005): 227-41, https://doi.org/10.1080/0950069042000325861.

5 Okechukwu S Abonyi, Lawrence Achimugu, and $\mathrm{M}$ Njoku, "Innovations in Science and Technology Education: A Case for Ethnoscience Based Science Classrooms," International Journal of Scientific and Engineering Research 5, no. $1 \quad$ (2014): 52-56, https://www.academia.edu/download/33498416/Innovations-in-Science-and-Technology-Education.pdf.

${ }^{6}$ Muh Fahrurrozi, "Pembelajaran Berbasis Budaya: Model Inovasi Pembelajaran Dan Implementasi Kurikulum Berbasis Kompetensi" (Prosiding Seminar Nasional dan Call For Papers Pendidikan Karakter dalam Pembelajaran Bisnis dan Manajemen, Malang: Surya Pena Gemilang, 2015), https://www.researchgate.net/profile/Diana-

Wulandari/publication/324258503_Kompetensi_dan_Karakter_Peserta_Didik_Perspektif_Multiple_Intell egences_Howard_Gardner/links/5ac77b95aca272abdc5ce4f5/Kompetensi-dan-Karakter-Peserta-DidikPerspektif-Multiple-Intellegences-Howard-Gardner.pdf.

${ }^{7}$ Anita Fibonacci, "Development Fun-Chem Learning Materials Integrated Socio-Science Issues To Increase Students Scientific Literacy," International Journal of Science and Research 3, no. 11 (2014): 708-13, https://www.ijsr.net/archive/v3i11/T0NUMTQxMDMz.pdf.

${ }^{8}$ Isna Amanatul Hayati, Dadan Rosana, and Sukardiyono Sukardiyono, "Pengembangan Modul Potensi Lokal Berbasis SETS Untuk Meningkatkan Keterampilan Proses IPA," Jurnal Inovasi Pendidikan IPA 5, no. 2 (October 2, 2019): 248-57, https://doi.org/10.21831/jipi.v5i2.27519.

9 Faikul Umam Umam, "Pemurnian Garam Dengan Metode Rekristalisasi Di Desa Bunder Pamekasan Untuk Mencapai SNI Garam Dapur," Jurnal Ilmiah Pangabdhi 5, no. 1 (April 20, 2019), https://doi.org/10.21107/pangabdhi.v5i1.5161. 
pond area of Padelegan village, Pamekasan city has its characteristics and uniqueness that science concept can be scientifically certified. ${ }^{10}$ Therefore, students in the surrounding environment need to know the concepts and habits of the surrounding community. This effort will facilitate the use of cultural knowledge as a reference in science learning. Integration of local potential in science learning is done for students not to forget their identity and are expected to develop local potentials owned in their respective regions. ${ }^{11}$

The outdoor learning model invites students out of the classroom; hence, it has a positive impact. ${ }^{12}$ Furthermore, it provides authentic experiences in learning new material and making education meaningful. Outdoor learning contributes significantly to effective processes and outputs. ${ }^{13}$ It also has a consistently positive impact on academics and selfconfidence. ${ }^{14}$ On average, those who have participated in impactful out-of-class activities make progress in about three additional months. ${ }^{15}$

Outdoor learning contributes significantly to effective processes and outputs. This study integrated outdoor learning into the student experience with the ethnoscience module. Therefore, students can choose the learning to be implemented in the classroom or outside through experimental activities. This research is a development of previous studies that emphasized only the ethnoscience module. ${ }^{16}$ Hence, this study aims to develop an outdoor learning activity-oriented ethnoscience module that is valid and

${ }^{10}$ Wiwin Puspita Hadi and Mochammad Ahied, "Kajian Ilmiah Proses Produksi Garam Di Madura Sebagai Sumber Belajar Kimia," J-PEK (Jurnal Pembelajaran Kimia) 2, no. 2 (December 28, 2018): 1-8, https://doi.org/10.17977/um026v2i22017p001.

11 Ahmad Khoiri, Almira Syifa, and Nurul Mubin, "Potential Local Physics Based Learning of Jepara District To Improve Science Process Skills and Students Entrepreneurship," Formatif: Jurnal Ilmiah Pendidikan MIPA 8, no. 1 (April 11, 2018), https://doi.org/10.30998/formatif.v8i1.2365.

12 Caroline Fiennes et al., The Existing Evidence-Base About The Effectiveness Of Outdoor Learning (London, UK: Giving Gvidence,2015), https://www.outdoorlearning.org/Portals/0/IOL\%20Documents/Research/outdoor-learning-giving-evidence-revised-finalreport-nov-2015-etc-v21.pdf?ver=2017-03-16-110244-937.

13 Justin Dillon, Mark Rickinson, and Kelly Teamey, "The Value of Outdoor Learning: Evidence from Research in the UK and Elsewhere," in Towards a Convergence Between Science and Environmental Education (Routledge, 2016), 193-200, https://www.taylorfrancis.com/books/edit/10.4324/9781315730486/towards-convergence-scienceenvironmental-education-justin-dillon?refId=ffdaf327-89b0-4b54-b960-57b6deb7261f.

${ }^{14}$ Ia Eriksson-Dobrovich, Learning Outdoors. Handbook for Adults with Mental Disabilities, (Learning in Motion. Uppsala: Studiefrämjandet, 2007).

${ }^{15}$ S. Higgins et al., "The Sutton Trust-Education Endowment Foundation Teaching And Learning Toolkit.," Monograph, Manual. Education Endowment Foundation, London. (London: Education Endowment Foundation, December 1, 2016), https://educationendowmentfoundation.org.uk/resources/teaching-learning-toolkit.

${ }^{16}$ Wiwin Eka Rahayu and Sudarmin Sudarmin, "Pengembangan Modul IPA Terpadu Berbasis Etnosains Tema Energi Dalam Kehidupan Untuk Menanamkan Jiwa Konservasi Siswa," Unnes Science Education Journal 4, no. 2 (July 19, 2015), https://doi.org/10.15294/usej.v4i2.7943. 
effective. This module development is done to improve the understanding of student science concepts in thematic learning in elementary schools.

\section{RESEARCH METHODS}

This study used the R\&D (Research and Development) method to define, design, develop, and disseminate. ${ }^{17}$ In the first phase of define, curriculum, student characteristics, and material analyses were performed. Therefore, exploration is important as the first step to determine both simple and complex problems. ${ }^{18}$

Further development is carried out at a later stage. At the second stage, the research team designed the product of the ethnoscience module to be developed. These included preparing problem item instruments, selecting the instructional design, and designing students' learning experiences during learning using the modules. This stage was done to obtain the initial prototype format of the learning module. The third stage was the development stage, and the activities involved conducting validation tests to the expert validators of materials and learning design. The material expert validators measured the suitability of module materials with basic competencies and learning indicators.

The experts validated the suitability of learning design used as the basis for implementing ethnoscience modules strategy. The product trials were conducted through simple random sampling, namely small and large group trials. The small group was conducted by heterogeneously giving modules to 10 grade VI students without regard to gender or competence. The students were asked to study the module, fill out a problem exercise, and take the final test to measure the effectiveness.

Implementation of a large group trial was conducted on 40 students of different gender and academic ability. This trial aims to determine the practicality level and

\footnotetext{
${ }^{17}$ Thiagarajan Sivasailam, Dorothy S. Semmel, and Melvyn I. Semmel, Instructional Development for Training Teachers of Exceptional Children, ( Bloomington: Indiana University, 1974).

${ }^{18}$ Hendra Hidayat et al., "Designing Of Technopreneurship Scientific Learning Framework In Vocational-Based Higher Education In Indonesia," International Journal of Engineering and Technology (UAE) 7, no. 4 (2018): 123-27, https://www.researchgate.net/profile/HendraHidayat/publication/328234208_Designing_of_Technopreneurship_Scientific_Learning_Framework_in_ Vocational-based_Higher_Education_in_Indonesia/links/5c68aa204585156b570156d0/Designing-ofTechnopreneurship-Scientific-Learning-Framework-in-Vocational-based-Higher-Education-inIndonesia.pdf.
} 
effectiveness of the product: ${ }^{19}$ Students were asked to experiment in salt ponds using the outdoor learning module. The study involved students of class VI SDN Padelegan Pademawu, Pamekasan as the subjects in the 2019/2020 school year. Furthermore, the students were of different gender and academic abilities. The learning materials used in the research were changes in the object's form.

The instruments used in data collection were in the form of questionnaires and test learning results. Meanwhile, the validity test was used to determine the product's validity before being implemented. ${ }^{20}$ Also, validator result data was used to measure the validity of the modules. The learning outcomes test instrument was given to students as a pre-test and post-test listed in the module. The test data of the learning results were used to determine the level of effectiveness. In addition, during the learning, students were given a questionnaire sheet to evaluate their responses. After learning, the post-test results were analyzed to determine the module's effectiveness. ${ }^{21}$

Data analysis consisted of validity and effectiveness. The validity of the products developed comes from the validation results performed by validators and learning design experts. Furthermore, the data were obtained in the form of qualitative and quantitative data. The quantitative data was in the form of validator assessment scores, while qualitative was in product suggestions and revisions from validators. Analysis of the module effectiveness was obtained from the test of learning results. In addition, student learning outcomes data were in the form of pre-test and post-test results. Finally, two samples t-test and $\mathrm{N}$ gain test were carried out. ${ }^{22}$

\section{RESULT AND DISCUSSION}

The concept of ethnoscience has been widely developed. Hence, it will be interesting when the ethnoscience used is based on outdoor activities and uses learning

\footnotetext{
${ }^{19}$ Tati Sumiati et al., "Indigenous Wisdom and Technology-Enabled Learning: Efforts to Prepare LPTK Graduates for the 21st Century" (3rd International Conference on Learning Innovation and Quality Education (ICLIQE 2019), Atlantis Press, 2020), 1313-20, https://www.atlantispress.com/article/125933489.pdf. Students."

${ }^{20}$ Davison and Miller, “An Ethnoscience Approach To Curriculum Issues For American Indian

${ }^{21}$ Fibonacci, "Development Fun-Chem Learning Materials Integrated Socio-Science Issues To Increase Students Scientific Literacy.”

${ }^{22}$ Wiyanto, S. E. Nugroho, and Hartono, "The Scientific Approach Learning: How Prospective Science Teachers Understand about Questioning," Journal of Physics: Conference Series 824 (April 2017): 012015, https://doi.org/10.1088/1742-6596/824/1/012015.
} 
materials (modules) that allow students to learn independently with or without the guidance of their teacher. This study aims to produce a module on ethnoscience outdoor learning strategy. The data description of the results is described using 4D stages as follows. $^{23}$

\section{Define Stage}

The define stage is carried out through a final initial analysis to identify the school's problems in the learning process. Field studies showed that salt ponds surround schools, and the introduction of local potential to students is still limited due to some challenges. In line with development, local potential has not been optimally explored. This condition leads to students' difficulty in understanding. ${ }^{24}$ Also, teaching materials in the learning process have never been integrated with the local potential of the area. For character analysis, students of SDN Padelegan Pamekasan have heterogeneous characteristics of academic ability level and gender.

Meanwhile, out of the 40 students, the academic ability level was low in 9 females and ten males. Also, the ability level was low in 6 female students and six males. For high academic abilities, there were one male and eight females. The detail is seen in figure 1.

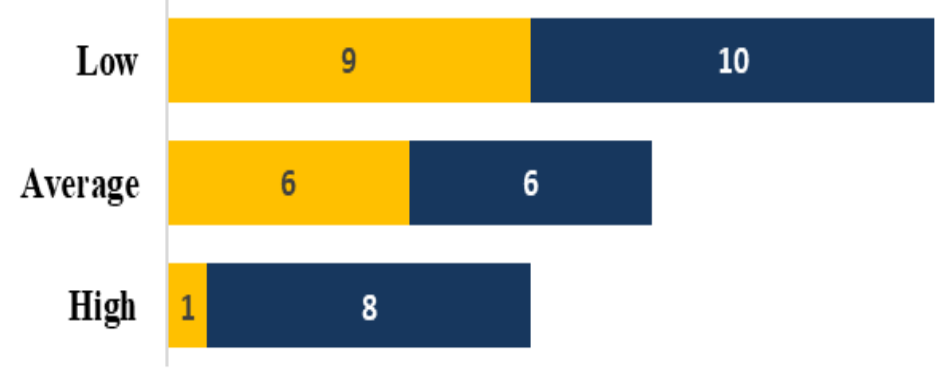

\section{$\square$ Male $\square$ Female}

Figure 1

Student's Prior Knowledge and Gender

23 Sivasailam, Semmel, and Semmel, "Instructional Development for Training Teachers of Exceptional Children."

${ }^{24}$ Andam S. Ardan, "The Development of Biology Teaching Material Based on the Local Wisdom of Timorese to Improve Students Knowledge and Attitude of Environment in Caring the Preservation of Environment," International Journal of Higher Education 5, no. 3 (2016): 190-200, https://eric.ed.gov/?id=EJ1111069. 
Women are subordinated to men; hence, they are thought to have lower academic achievement than men. ${ }^{25}$ However, in contrast to the conditions in this school, female students have higher academic ability than males. This fact is an indisputable theory of academic achievement judging by gender, with conditions in the field.

After knowing the students' characteristics, a material analysis was performed. The learning materials that are by the conditions of local potential are changes in the object's form. Furthermore, the indicators that are interrelated with the material were arranged continuously to form concepts. Therefore, it is necessary to analyze to identify concepts related to the developed learning material. ${ }^{26}$

\section{Design}

The design stage consisted of several steps, including the Preparation of Benchmark Reference Test. The tests were conducted by compiling the instruments used. Furthermore, pre-test and post-test problems were developed according to the learning indicators in the module. The development of authentic instruments allows teachers to see the competencies of students observed in real learning. Therefore, it is expected that pre-test and post-test are procedurally prepared and can comprehensively measure students' competence.

The next step, which is selecting the format, is adjusted to the sub-theme of the IPA payload environment to change the form of objects. Meanwhile, the module format consists of the beginning, the core part, and the end. In addition, modules have different characteristics, where they are self-taught learning materials for students. ${ }^{27}$

There are five phases, all of which are interrelated with each other. (1) analyzing goal, (2) Study the potential and needs of courses, (3) planning, (4) implementation, and

\footnotetext{
${ }^{25}$ Sartini Nuryoto, "Perbedaan Prestasi Akademik Antara Laki-Laki Dan Perempuan Studi Di Wilayah Yogyakarta," Jurnal Psikologi 25, no. 2 (1998): 127308, https://core.ac.uk/download/pdf/291850893.pdf.

${ }^{26}$ Riza Nur Cahyaningtyas, Insih Wilujeng, and I. Gusti Putu Suryadarma, "The Effect Of Science Learning Based On An Integrated Scientific Approach To Local Potential On The Science Process Skill Of The Student," Unnes Science Education Journal 6, no. 2 (July 31, 2017), https://doi.org/10.15294/usej.v6i2.15857.

${ }^{27}$ Andika Adinanda Siswoyo et al., "Management of Outdoor Learning Models for Environmental Education Courses," Universal Journal of Educational Research 8, no. 11 (October 2020): 5036-43, https://doi.org/10.13189/ujer.2020.081103.
} 
(5) evaluation. ${ }^{28}$ In each submodule, some activities integrate outdoor learning. Also, activities outside the classroom show a better impact on students. ${ }^{29}$

\section{Develop}

The developmental phase consists of expert validation and field trials. This phase includes learning material and design experts, who measure aspects of relevance, and the degree of difficulty in the module. Meanwhile, the learning design validator measures planning similarity, module substance, and relevance of the student's learning experience. The validation results of the outdoor learning module are seen in table 1.

Table 1

Validator Assessment Result

\begin{tabular}{ccc}
\hline Validator & Skor & Kategori \\
\hline Material Validator & 3,50 & Good \\
\hline Instructional Design Validator & 3,60 & Good \\
\hline
\end{tabular}

Based on table 2. The products developed are in the valid category, in terms of materials and learning design. Therefore, the module strategy is validly used. The validity of learning materials is important for teaching because it becomes the content that determines the success of learning objectives. ${ }^{30}$ The assessment of validators is also accompanied by suggestions and feedback to make revisions to the developed products.

Some of the suggestions and inputs given include (1) the images in the module should be clear, (2) the systematics should be coherent, (3) the interaction of environmental components should be depicted with real photos, (4) present factual examples of student activity during learning in salt ponds. This revision is done to improve the content and appearance of the modules developed. Meanwhile, the field test was conducted on grade VI students at SDN Padelegan, Pamekasan. The testing began with pre-testing and measuring students' initial abilities. The students were then invited to salt ponds to experiment and observe the process of changing the form of substances in accordance with the outdoor learning strategy.

28 I. Wayan Santyasa, Assesmen dan Evaluasi Pembelajaran Fisika (Graha Ilmu, 2017), http://repo.iainbatusangkar.ac.id/xmlui/handle/123456789/9332.

${ }^{29}$ M.R. Baker, T. M. Waliczek, and J. M. Zajicek, "The Effect of School Gardening Activities on Visual-Motor Integration of Pre-School and Kindergarten Students," Journal of Therapeutic Horticulture 25, no. 2 (2015): 3-14, https://www.jstor.org/stable/24865264.

${ }^{30}$ Santyasa, Assesmen dan Evaluasi Pembelajaran Fisika. 
The application of outdoor learning reduces depression because the learning model is very fun and increases physical activity through learning outside the classroom. ${ }^{31}$ Once completed, students work on the post-test inside the module. The outcomes of understanding the concepts of science in thematic learning are shown in Table 2.

Table 2

Result Of Learning Outcome

\begin{tabular}{ccccc}
\hline No & Aspect & Pre-Test & Post-Test & n-gain \\
\hline 1 & Number Of Students & 40 & 40 & 40 \\
\hline 2 & Highest Score & 80 & 90 & \\
\hline 3 & Lowest Score & 25 & 35 & \\
\hline 4 & Average & 55,6 & 71,75 & 0,35 (sedang) \\
\hline 5 & Percentage of Minimum Criteria & $25 \%$ & $65 \%$ & \\
\hline & Score & & \\
\hline
\end{tabular}

Descriptively and qualitatively, table 2 shows the highest pre-test, and the posttest score is 80 and 90, respectively. The average pre-test student is 55.6 , while the posttest is $71.75 \%$. From the results of the n-gain test against 40 students, an average of 0.35 was obtained with a moderate category. The results of science understanding based on the achievement of minimum completion criteria in the pre-test and post-test can be seen in figure 2.

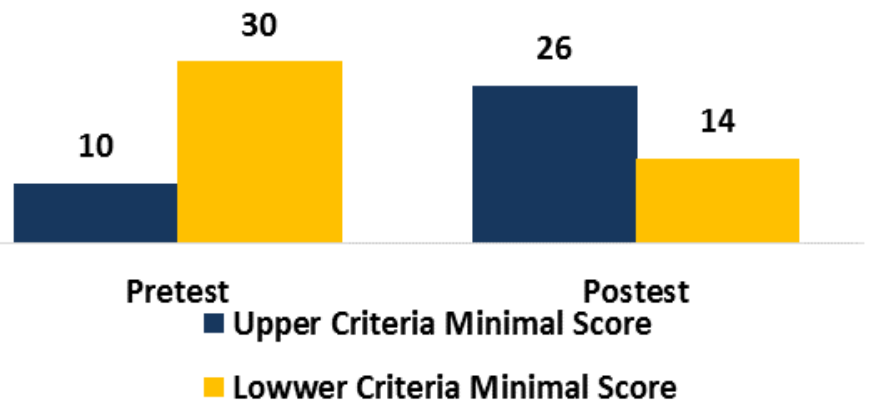

Figure 2

Result Of Student's Learning Outcome

31 Eriksson-Dobrovich, "Learning Outdoors. Handbook for Adults with Mental Disabilities. Learning in Motion. Uppsala.” 


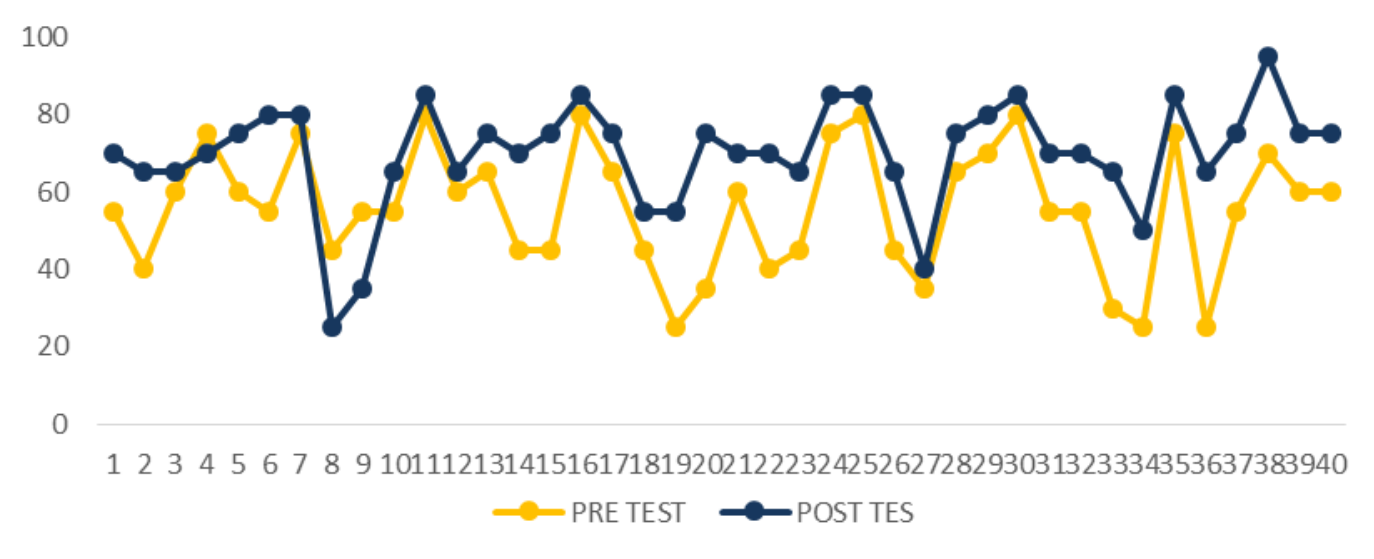

\section{Figure 3}

Graphic Of Student's Learning Outcome

Based on figure 3, the distribution of pre-test and post-test students' grades can be seen. The application of outdoor learning modules influences the average increase in learning outcomes of understanding science concepts. This finding is following the results that integrated science-assisted learning has the potential to improve science concepts. ${ }^{32}$ Moreover, The outdoor strategy empowers students in obtaining information through outside learning and accustoms them to overcome problems. ${ }^{33}$ Outdoor learning is not just an effort to find the right answer but rather to find a way to solve the right problem. ${ }^{34}$

Therefore, the collaboration of ethnoscience and outdoor learning has a positive impact on understanding science concepts. This collaboration will help students solve the problems that occur around them. Moreover, ethnoscience-based learning helps in the cultural preservation and self-development of students' culture. ${ }^{35}$

Based on the results of inferential statistical tests, using t-test, the data obtained showed $t$ stat of -6.61 . This value is the same as in paired t-test materials. The hypothesis

${ }^{32}$ Cahyaningtyas, Wilujeng, and Suryadarma, "The Effect of Science Learning Based on an Integrated Scientific Approach to Local Potential on the Science Process Skill of the Student."

${ }^{33}$ Tom Holman and Leo McAvoy, "Outcomes-Consequences-Values Of An Integrated Wilderness Adventure Program - Proquest," The Journal of Experiential Education 25, no. 3 (2003): 353, https://www.proquest.com/openview/539674dffb87a6c37ee3af099c125af0/1?pqorigsite $=$ gscholar $\& \mathrm{cbl}=47692$.

${ }^{34}$ Anthony J Cuvo, Michael E May, and Tiffany M Post, "Effects Of Living Room, Snoezelen Room, And Outdoor Activities On Stereotypic Behavior And Engagement By Adults With Profound Mental Retardation," Research in Developmental Disabilities 22, no. 3 (May 1, 2001): 183-204, https://doi.org/10.1016/S0891-4222(01)00067-1.

35 Mohammad Anisuzzaman Chowdhury, "The Integration of Science-TechnologySociety/Science-Technology-Society- Environment and Socio-Scientific-Issues for Effective Science Education and Science Teaching," Electronic Journal of Science Education 20, no. 5 (2016): 19-38, https://eric.ed.gov/?id=EJ1188220. 
used was two-way that used two tails. The result of the $t$ table was 2.02 with a p-value of 0.0000000083 . Because the $p$-value is smaller than alpha $5 \%$ or by looking at the $\mid t$ count| $>\mathrm{t}$ table, the decision rejects Ho. Ho was rejected, and it was concluded that there was a significant difference between the learning outcomes before and after the module was implemented. This finding is seen in figure 4 .

\begin{tabular}{lrr}
\hline & 55 & \multicolumn{1}{c}{57} \\
\hline Mean & 55,64103 & 71,74359 \\
Variance & 267,3414 & 202,5641 \\
Observations & 39 & 39 \\
Pearson Correlation & 0,628342 & \\
Hypothesized Mean Difference & 0 & \\
Df & 38 & \\
$\mathrm{t}$ Stat & $-6,611144$ & \\
$\mathrm{P}(\mathrm{T}<=\mathrm{t})$ one tail & $4,15 \mathrm{E}-08$ & \\
$\mathrm{t}$ critical one tail & 1,685954 & \\
$\mathrm{P}(\mathrm{T}<=\mathrm{t})$ two-tail & $8,30 \mathrm{E}-08$ & \\
$\mathrm{t}$ critical two-tail & 2,024394 & \\
\hline
\end{tabular}

Figure 4

Result t-Test: Paired Two Sample for Means

There is a difference in average between pre-test and post-test from results of the t-test and n-gain test in the moderate category. Therefore, it can be determined whether the learning module is effective for thematic learning in elementary schools, especially in Padelegan area, Pamekasan.

\section{CONCLUSION}

The thematic module based on the outdoor learning strategy is worth using and improving the understanding of science concepts in thematic learning in primary schools. The validity of this module reached an average score of 3.55 , which was obtained from the expert and learning design validator. Furthermore, the thematic module is effectively used judging by the results of the t-test test that showed there was a difference in the average pre-test and post-test students. In addition, the understanding of student concepts before and after learning also improved. This finding is shown through the n-gain test of 0.35 with a moderate category.

Other research teams who want to study further can relate to other local potentials on the Madura island, which can be integrated into learning. They can also use larger samples to obtain an accurate result and better describe the actual situation. 


\section{ACKNOWLEDGMENTS}

Universitas Trunojoyo Madura.

\section{DECLARATION OF CONFLICTING INTERESTS}

The author/s declared no potential conflicts of interest with respect to the research, authorship, and/or publication of this article.

\section{FUNDING}

Private funds were used to support this research.

\section{ORCID iD}

Andika Adinanda Siswoyo iD https://orcid.org/0000-0002-0234-9578

\section{REFERENCE}

Abonyi, Okechukwu S, Lawrence Achimugu, and M Njoku. "Innovations in Science and Technology Education: A Case for Ethnoscience Based Science Classrooms." International Journal of Scientific and Engineering Research 5, no. 1 (2014): 5256. https://www.academia.edu/download/33498416/Innovations-in-Science-andTechnology-Education.pdf.

Ardan, Andam S. "The Development of Biology Teaching Material Based on the Local Wisdom of Timorese to Improve Students Knowledge and Attitude of Environment in Caring the Preservation of Environment." International Journal of Higher Education 5, no. 3 (2016): 190-200. https://eric.ed.gov/?id=EJ1111069.

Baker, M.R., T. M. Waliczek, and J. M. Zajicek. "The Effect of School Gardening Activities on Visual-Motor Integration of Pre-School and Kindergarten Students." Journal of Therapeutic Horticulture 25, no. 2 (2015): 3-14. https://www.jstor.org/stable/24865264.

Cahyaningtyas, Riza Nur, Insih Wilujeng, and I. Gusti Putu Suryadarma. "The Effect Of Science Learning Based On An Integrated Scientific Approach To Local Potential On The Science Process Skill Of The Student." Unnes Science Education Journal 6, no. 2 (July 31, 2017). https://doi.org/10.15294/usej.v6i2.15857.

Chowdhury, Mohammad Anisuzzaman. "The Integration of Science-TechnologySociety/Science-Technology-Society- Environment and Socio-Scientific-Issues for Effective Science Education and Science Teaching." Electronic Journal of Science Education 20, no. 5 (2016): 19-38. https://eric.ed.gov/?id=EJ1188220.

Cuvo, Anthony J, Michael E May, and Tiffany M Post. "Effects Of Living Room, Snoezelen Room, And Outdoor Activities On Stereotypic Behavior And Engagement By Adults With Profound Mental Retardation." Research in Developmental Disabilities 22, no. 3 (May 1, 2001): 183-204. https://doi.org/10.1016/S0891-4222(01)00067-1.

Davison, David M., and Kenneth W. Miller. "An Ethnoscience Approach to Curriculum Issues for American Indian Students." School Science and Mathematics 98, no. 5 (1998): 260-65. https://doi.org/10.1111/j.1949-8594.1998.tb17299.x. 
Dillon, Justin, Mark Rickinson, and Kelly Teamey. "The Value of Outdoor Learning: Evidence from Research in the UK and Elsewhere." In Towards a Convergence Between Science and Environmental Education, 193-200. Routledge, 2016. https://www.taylorfrancis.com/books/edit/10.4324/9781315730486/towardsconvergence-science-environmental-education-justin-dillon?refId=ffdaf327-89b04b54-b960-57b6deb7261f.

Eriksson-Dobrovich, Ia. Learning Outdoors. Handbook for Adults with Mental Disabilities. Learning in Motion. Uppsala: Studiefrämjandet,” 2007.

Fahrurrozi, Muh. "Pembelajaran Berbasis Budaya: Model Inovasi Pembelajaran Dan Implementasi Kurikulum Berbasis Kompetensi." Malang: Surya Pena Gemilang, 2015. https://www.researchgate.net/profile/DianaWulandari/publication/324258503_Kompetensi_dan_Karakter_Peserta_Didik_Per spektif_Multiple_Intellegences_Howard_Gardner/links/5ac77b95aca272abdc5ce4 f5/Kompetensi-dan-Karakter-Peserta-Didik-Perspektif-Multiple-IntellegencesHoward-Gardner.pdf.

Fibonacci, Anita. "Development Fun-Chem Learning Materials Integrated Socio-Science Issues To Increase Students Scientific Literacy." International Journal of Science and Research 3, no. 11 (2014): 708-13. https://www.ijsr.net/archive/v3i11/T0NUMTQxMDMz.pdf.

Fiennes, Caroline, Elizabeth Oliver, Kelly Dickson, Diego Escobar, Amy Romans, and Sandy Oliver. The Existing Evidence-Base About The Effectiveness Of Outdoor Learning. London, UK: Giving Evidence, 2015. https://www.outdoorlearning.org/Portals/0/IOL\%20Documents/Research/outdoor-learning-givingevidence-revised-final-report-nov-2015-etc-v21.pdf?ver=2017-03-16-110244937.

Hadi, Wiwin Puspita, and Mochammad Ahied. "Kajian Ilmiah Proses Produksi Garam Di Madura Sebagai Sumber Belajar Kimia.” J-PEK (Jurnal Pembelajaran Kimia) 2, no. 2 (December 28, 2018): 1-8. https://doi.org/10.17977/um026v2i22017p001.

Hayati, Isna Amanatul, Dadan Rosana, and Sukardiyono Sukardiyono. "Pengembangan Modul Potensi Lokal Berbasis SETS Untuk Meningkatkan Keterampilan Proses IPA." Jurnal Inovasi Pendidikan IPA 5, no. 2 (October 2, 2019): 248-57. https://doi.org/10.21831/jipi.v5i2.27519.

Hidayat, Hendra, S Herawati, E Syahmaidi, A Hidayati, and Z Ardi. "Designing Of Technopreneurship Scientific Learning Framework In Vocational-Based Higher Education In Indonesia." International Journal of Engineering and Technology (UAE) 7, no. 4 (2018): 123-27. https://www.researchgate.net/profile/HendraHidayat/publication/328234208_Designing_of_Technopreneurship_Scientific_ Learning_Framework_in_Vocationalbased_Higher_Education_in_Indonesia/links/5c68aa204585156b570156d0/Desig ning-of-Technopreneurship-Scientific-Learning-Framework-in-Vocational-basedHigher-Education-in-Indonesia.pdf.

Higgins, S., M. Katsipataki, A. B. Villanueva-Aguilera, R. Coleman, P. Henderson, L. E. Major, R. Coe, and D. Mason. "The Sutton Trust-Education Endowment Foundation Teaching And Learning Toolkit." Monograph. Manual. Education Endowment Foundation, London. London: Education Endowment Foundation, 
December

1 ,

2016.

https://educationendowmentfoundation.org.uk/resources/teaching-learning-toolkit.

Holman, Tom, and Leo McAvoy. "Outcomes-Consequences-Values Of An Integrated Wilderness Adventure Program - Proquest." The Journal of Experiential Education 25, no. 353. https://www.proquest.com/openview/539674dffb87a6c37ee3af099c125af0/1?pqorigsite $=$ gscholar\&cbl $=47692$.

Kasa, I Wayan. "Local Wisdom In Relation To Climate Change." Journal of ISSAAS 17, no. 1 (2011): 22-27. https://www.cabdirect.org/cabdirect/abstract/20113247888.

Khoiri, Ahmad, Almira Syifa, and Nurul Mubin. "Potential Local Physics Based Learning of Jepara District To Improve Science Process Skills and Students Entrepreneurship." Formatif: Jurnal Ilmiah Pendidikan MIPA 8, no. 1 (April 11, 2018). https://doi.org/10.30998/formatif.v8i1.2365.

McKinley, Elizabeth. "Locating The Global: Culture, Language And Science Education For Indigenous Students." International Journal of Science Education 27, no. 2 (January 1, 2005): 227-41. https://doi.org/10.1080/0950069042000325861.

Nuryoto, Sartini. "Perbedaan Prestasi Akademik Antara Laki-Laki Dan Perempuan Studi Di Wilayah Yogyakarta." Jurnal Psikologi 25, no. 2 (1998): 127308. https://core.ac.uk/download/pdf/291850893.pdf.

Rahayu, Wiwin Eka, and Sudarmin Sudarmin. "Pengembangan Modul IPA Terpadu Berbasis Etnosains Tema Energi Dalam Kehidupan Untuk Menanamkan Jiwa Konservasi Siswa." Unnes Science Education Journal 4, no. 2 (July 19, 2015). https://doi.org/10.15294/usej.v4i2.7943.

Santyasa, I. Wayan. Assesmen dan Evaluasi Pembelajaran Fisika. Graha Ilmu, 2017. http://repo.iainbatusangkar.ac.id/xmlui/handle/123456789/9332.

Siswoyo, Andika Adinanda, Agung Setyawan, Tyasmiarni Citrawati, Rita Prima Bendriyanti, and Citra Dewi. "Management of Outdoor Learning Models for Environmental Education Courses." Universal Journal of Educational Research 8, no. 11 (October 2020): 5036-43. https://doi.org/10.13189/ujer.2020.081103.

Sivasailam, Thiagarajan, Dorothy S. Semmel, and Melvyn I. Semmel. Instructional Development for Training Teachers of Exceptional Children. Bloomington: Indiana University, 1974.

Sumiati, Tati, Nuur Wachid Abdul Majid, Chandra Motilal, and Dini Indrian. "Indigenous Wisdom and Technology-Enabled Learning: Efforts to Prepare LPTK Graduates for the 21st Century," 1313-20. Atlantis Press, 2020. https://www.atlantispress.com/article/125933489.pdf.

Umam, Faikul Umam. "Pemurnian Garam Dengan Metode Rekristalisasi Di Desa Bunder Pamekasan Untuk Mencapai SNI Garam Dapur.” Jurnal Ilmiah Pangabdhi 5, no. 1 (April 20, 2019). https://doi.org/10.21107/pangabdhi.v5i1.5161.

Usmeldi, and Risda Amini. "The Effect Of Integrated Science Learning Based On Local Wisdom To Increase The Students Competency." Journal of Physics: Conference Series 1470 (February 2020): 012028. https://doi.org/10.1088/17426596/1470/1/012028. 
Wiyanto, S. E. Nugroho, and Hartono. "The Scientific Approach Learning: How Prospective Science Teachers Understand about Questioning." Journal of Physics: Conference Series 824 (April 2017): 012015. https://doi.org/10.1088/1742$6596 / 824 / 1 / 012015$. 
This page is intentionally left blank 